\title{
Hydrological science and wetland restoration: some case studies from Europe
}

\author{
M.C. Acreman, J. Fisher, C.J. Stratford, D.J. Mould and J.O. Mountford \\ Centre for Ecology and Hydrology, Wallingford, UK \\ Email for corresponding author: man@ceh.ac.uk
}

\begin{abstract}
Throughout the world, wetlands are increasingly being recognised as important elements of the landscape because of their high biodiversity and goods and services they provide to mankind. After many decades of wetland destruction and conversion, large areas of wetlands are now protected under the International Convention on Wetlands (Ramsar) and regional or national legislation such as the European Union Habitats Directive. In many cases, there is a need to restore the ecological character of the wetland through appropriate water management. This paper provides examples of scientific knowledge of wetland hydrology that can guide such restoration. It focuses on the need for sound hydrological science on a range of issues including water level control, topography, flood storage, wetland connections with rivers and sustainability of water supply under climate change.
\end{abstract}

Keywords: wetlands, restoration, hydrological science, wet grassland, oxbow lake

\section{Introduction}

The term wetlands covers a wide range of ecosystem types including fens, swamps, blanket bogs, salt marshes and oxbow lakes under the International Convention on Wetlands (Davis, 1994), often called the Ramsar Convention after the town in Iran where it was signed. Wetlands cover $6 \%$ of the land surface of the Earth (OECD, 1996) but, through their biodiversity (Dugan, 1993), natural resources and buffering of the hydrological cycle (Bullock and Acreman, 2003), they have an important influence on the global environment. The critical global areas of wetland include the Pantanal in South America (Hamilton, 2002), the Okavango in southern Africa (Scudder et al., 1993), the inner Niger delta of west Africa (Zwarts et al., 2005), the Indus delta in Pakistan (Meynell and Qureshi, 1995), the peat swamps of Indonesia (Maltby et al., 1996) and the billabongs of south-east Australia (Young, 2001). European wetlands tend to be smaller than many of the global flagship sites, but are, nevertheless, recognised as vital elements of the European environment, e.g. for achieving good ecological status in all water bodies in partial fulfilment of the European Union's Water Framework Directive (WFD). However, wetland systems are vulnerable and particularly susceptible to changes in quantity and quality of water supply (Mitsch and Gosselink, 1993). Even small hydrological changes can lead to major changes in plant communities (Wheeler et al., 2004) and habitat for animals and many have been destroyed or degraded (Maltby, 1986). Particularly in the post-second-world-war period, farmers were encouraged through subsidies to drain wetlands to increase agricultural output. In addition, embankments have been built to protect floodplains from river flooding and abstraction of surface and groundwater for public supply, industry and agriculture has led to reduced water availability for wetlands. As a result, the world has lost around half its wetlands; the US, for example has lost $52 \%$ of its wetlands since European settlement (Dahl and Johnson, 1991). Even the wetlands that remain are still threatened by change; for example $50 \%$ of the 734 wetlands in Asia, for which data are available, were considered to be under moderate or serious threat (Scott and Poole, 1989). Some 57 wetland sites designated as globally important under the Ramsar Convention are on its Montreux list as degraded (http:// www.ramsar.org/key montreux record.htm).

More recently, the focus on wetlands has been to restore their natural characteristics and associated functions and 
values (Ramsar, 2000), with farmers encouraged or subsidised to maintain high water levels. The gradual change from site protection to 'creative conservation' began in 1935 in the American prairies; by 1990, ecologists and nature conservationists were very active in the rehabilitation of degraded habitats and, where these habitats had been entirely destroyed, in the re-creation of some approximation to the original (Sheail et al., 1997). Since hydrology is the most important determinant of the establishment and maintenance of wetlands (Mitsch and Gosselink, 1993; Hollis and Thompson, 1998), water management is the key to wetland restoration.

Restoration can be very expensive and time consuming and success cannot be guaranteed because of a lack of full understanding of the complex processes that determine the character of a wetland (Mitsch and Gosselink, 1993). To maximise the likelihood of success, restoration must be underpinned by sound science. Wetland restoration is a new, but growing, area of research and has been the subject of many major conferences (e.g. Wheeler et al., 1995). Whilst knowledge of hydrological processes of wetlands is growing, there are still many gaps in understanding exactly how best to restore the wetness to wetlands. In this paper, the major issues in the hydrological science of wetland restoration are presented through a series of European case studies (Fig. 1) and to highlight some pitfalls of restoration measures.

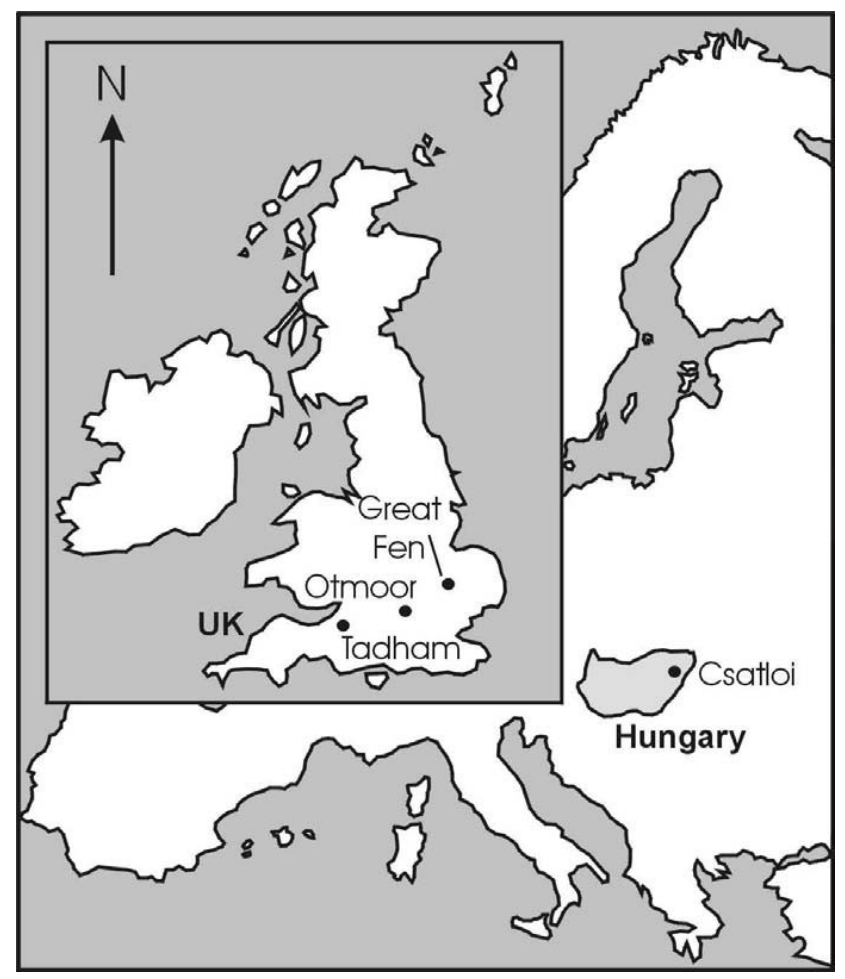

Fig. 1. Location of case study sites in Europe
The major issues are:

- Water availability for restoration at required times.

- The role of models in understanding and assessing the likely success of restoration.

- The effectiveness of ditch water level management on in-field wetness.

- The utility of reconnecting river channels to floodplains and oxbow lakes.

- The impact of restoration on the hydrological functions of wetlands.

\section{Making wetlands wet again: the cases of Tadham Moor and Otmoor, UK}

A water table level at or near the surface, either periodically or permanently, is widely recognised as a key characteristic of wetlands (Mitsch and Gosselink, 1993). High water table levels result from an excess of water input over water loss from the wetland and are, thus, a combination of hydrological conditions in a catchment (including rainfall, river flows and groundwater movement) and the permeability of the wetland soils. In many catchments containing wetlands, the hydrological cycle and, hence, water availability, have been altered significantly by water resources or flood protection measures to meet public water supply, agriculture or industrial needs. Even where restoration of wetlands is agreed by a wide range of stakeholders and forms part of river basin management plans, it may not be feasible to restore all hydrological processes in the catchment. Consequently, wetland restoration must be based on retaining high water table levels within the site, in situations where the water table in the surrounding land is much lower. At Wicken Fen in eastern England, for example, maintaining the wetland depends on a water-proof plastic membrane in the site's embankment, since arable farming has lowered, by some $5 \mathrm{~m}$, the level of the surrounding land, leaving the wetland perched and liable to drain completely if not protected (McCartney et al., 2000).

A key management tool at many European wetlands is the maintenance of high water levels in ditches using small water-retaining structures such as penning boards or sluice gates, often associated with pumps to transfer water into the wetland. A typical example is Tadham Moor in southwest England, a Site of Special Scientific Interest (SSSI) which is part of the Somerset Levels and Moors Special Protection Area for Birds under the Natura 2000 network. The soils of this wetland comprise 1 to $3 \mathrm{~m}$ of peat overlying marine clay. Over much of Tadham Moor, ditches, pumped to a low level in winter to stimulate agricultural land drainage, are kept high in summer to provide stock watering 


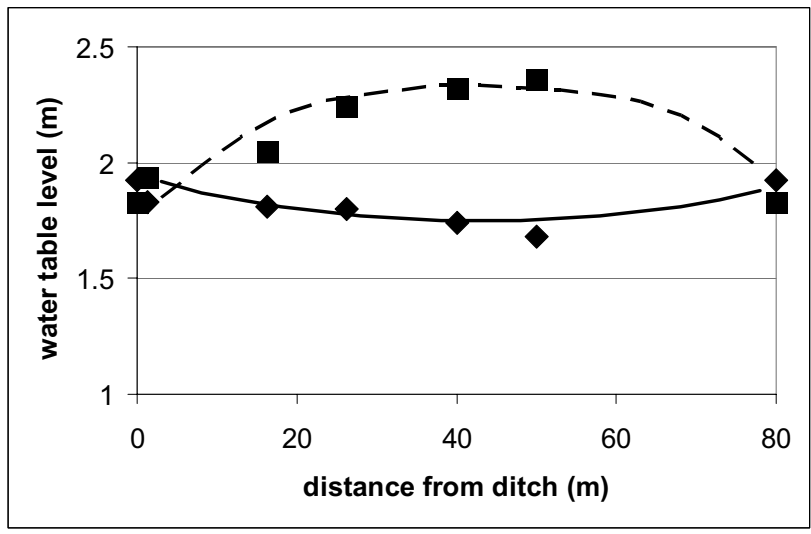

Fig. 2. Water table levels across an $80 \mathrm{~m}$ wide field at Tadham Moor bounded by ditches. Summer profile observed (diamonds) and modelled (solid line) and winter profile observed (squares) and modelled (dashed line).

and wet-fencing. This regime is known locally as Tier 1 and is quite different from the natural regime, which is characterised by winter flooding and drier summer conditions. Restoration of wetland conservation areas has involved using penning boards and pumps to keep ditch water levels at mean field level in the winter and $300 \mathrm{~mm}$ below this level in the summer (as part of a set of rules for environmentally sensitive management called Tier 3, for which farmers can receive subsidies of up to $£ 700$ per hectare per year). Most of the area has been levelled, removing the historical topography of the wetlands, including natural shallow channels called sloughs. Without these features, even when ditch water levels are at field level, water can move towards the centre of the field only by passing through the (possibly relatively impermeable) soil substrate and, hence, may penetrate only about 10 metres into the field, leaving the water table in the centre of the field controlled by rainfall and evaporation (Acreman et al., 2000). Figure 2 shows water table levels across a field at Tadham Moor in periods in winter and summer when ditch levels were approximately the same. Squares (observed dip well levels) and dashed line (modelled) are for the winter (19 December 1997) and diamonds (observed dip well levels) and solid line (modelled) are for the summer (31 July 1997). Thus, even in relatively permeable soils, ditch water level management alone may not achieve water table targets across a site.

In such cases, fuller control over water table levels in the wetland can be achieved only by restoring elements of the natural topography. Shallow ditches $(0.2-0.3 \mathrm{~m}$ deep, 2-3 m wide), called grips, have been cut in some wetlands (e.g. on the RSPB bird reserve at Otmoor in the UK - see Fig. 3) to connect main ditches with field interiors. The

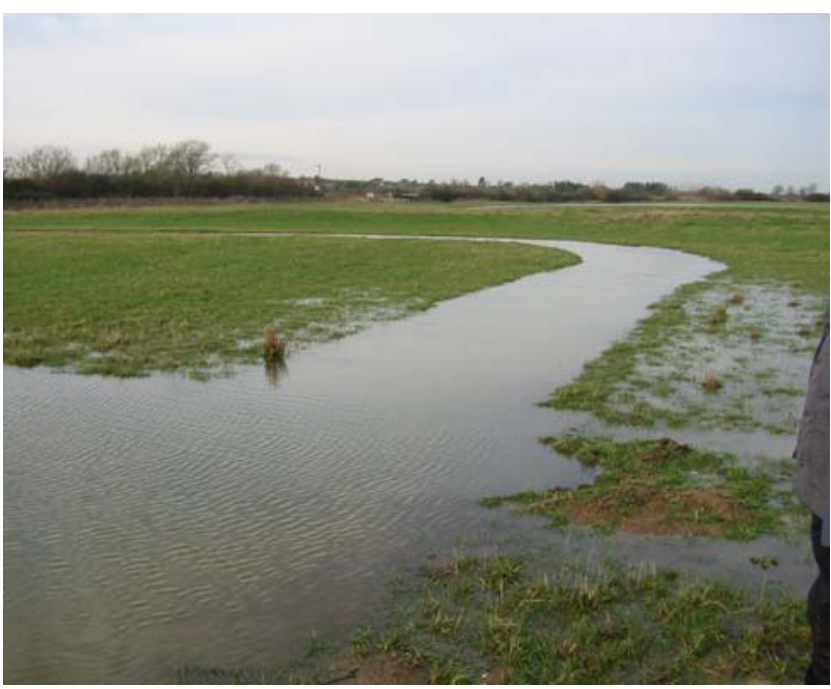

Fig.3. Grips at Otmoor

pattern of grips tended to be a regular grid rather than a natural dendritic type to allow efficient agricultural management practices, such as cutting hay by machine.

On Otmoor, a project funded by the UK Department of Environment, Food and Rural Affairs has been established to study the impact of installing grips at different spacings; 5,10 and $20 \mathrm{~m}$. Soil water was monitored at stations in transects perpendicular to the channels at distances $0.1,0.5$, $1.0,2.5,5.0$ and $10.0 \mathrm{~m}$ from the edge of the grip (where space permits, e.g. no $10 \mathrm{~m}$ stations between grips $5 \mathrm{~m}$ apart). Figure 4 shows a cross section profile through seven grips. The top line is the ground surface, the middle line is the water table when the grips contain water but conditions are getting drier (sample date 26/4/2005) and the dashed line shows the water table when the grips are dry but conditions are getting wetter (sample date 20/10/2005). Vertical lines indicate the locations of the grips. Clearly, in April the grips

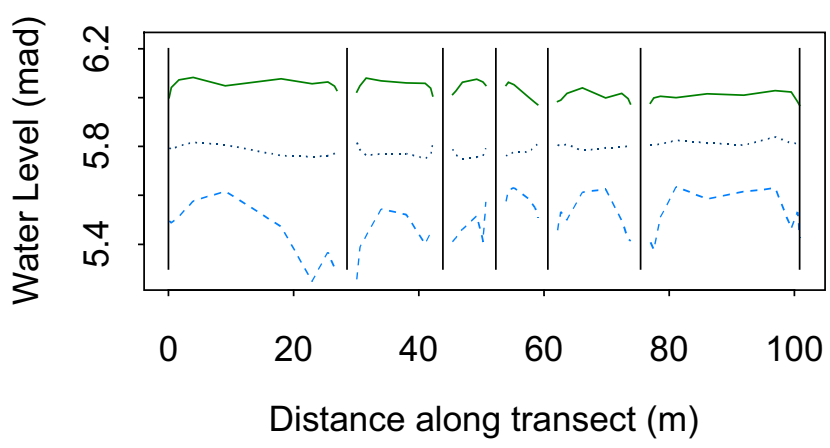

Fig. 4. Water table levels across a wetland where grips have been installed (the locations of the grips are marked by vertical lines). Top line $($ solid $)=$ ground surface, middle line $($ dotted $)=$ grips wet (26/4/2005), bottom line (dashed) $=$ grips dry (20/10/2005). 
were acting as irrigators with lower water tables between grips. In October, the reverse situation exists where the grips are draining water.

\section{Modelling wetland water table variations: the case of Tadham Moor, UK}

The hydrological processes associated with wetland restoration must be understood for various reasons. These include: quantification of the water requirements of water level control schemes (e.g. Tier 3), the effectiveness of raising or lowering ditch water levels in influencing in-field water table levels, and quantification of the effect of changing water table conditions on evaporation, vegetation diversity and soil microbial activity. Field-based manipulation experiments are essential to an understanding of the hydrological processes in wetlands, but they can be expensive, time-consuming and give only limited scope for studying different scenarios. The use of models in addition to field experiments is often less expensive and gives an opportunity to explore changes in conditions that would be difficult to impose in the field (e.g. increased rainfall or air temperature). A validated model of water table behaviour enables assessment of the effects of various water level management strategies and also of factors such as climate change.

A variety of models from steady-state, 1-dimensional to transient 3-dimensional have been used over a range of wetland types to simulate water table fluctuations (Bradford and Acreman, 2003). This work used the groundwater model Groundwater Vistas (GWV) v3, based on the widely available MODFLOW code (McDonald and Harburgh, 1988). The inclusion of wetlands within regional scale groundwater models will help understanding of whether a wetland is at risk from groundwater abstraction or is a significant source of recharge to a groundwater system (Whiteman et al., 2004). The use of a groundwater rather than a ditch drainage model was, therefore, felt to be justified, and GWV was particularly beneficial as it is currently the model preferred by the UK Environment Agency.

The site, within the Tadham Moor SSSI, has the benefit that, within an area of $\sim 60$ ha, individual fields, generally $300 \mathrm{~m}$ long and 40 to $80 \mathrm{~m}$ wide, are intersected by ditches, the water levels of which are either Tier 1 or Tier 3. Some fields are entirely surrounded by Tier 3 ditches, some by a combination of Tier 3 and Tier 1 ditches and some entirely by Tier 1 ditches. A network of dipwells was installed to obtain measurement of the unconfined water table. Ditch water levels were recorded at stage boards and an automatic weather station recorded meteorological variables such as wind speed, humidity, radiation and precipitation.

The model was set up initially for a 2-dimensional transect through a $70 \mathrm{~m}$-wide field with Tier 1 ditches on both sides. The monitoring dipwells are at 1.5, 4, 9.5, 20 and $40 \mathrm{~m}$ from the edge of one of the ditches. The peat was represented by a layer of uniform thickness $1.6 \mathrm{~m}$ and, in the absence of site-specific measurements of hydraulic characteristics, values for peat were taken from the literature. Fixed values were employed for specific storage $(0.0001)$ and porosity (0.24). Hydraulic conductivity and specific yield were both calibrated during model runs. The best fit value for hydraulic conductivity was $2.0 \mathrm{~m} \mathrm{day}^{-1}$ which is close to the $1.6 \mathrm{~m}$ day $^{-1}$ found by Bradley and Brown (1995). The optimum value of specific yield was 0.2 , which matched the 0.2 of Armstrong (1993). The model was run in transient mode on a daily time-step using as input data daily average ditch water level, daily total rainfall and daily evaporation derived from monthly mean values. The dipwells were monitored fortnightly throughout the modelled period and were used to calibrate the model.

Figure 5 shows the results of the calibrated model runs for dipwells 1 and 5. After an initial run-in period of

\section{Dipwell 1}

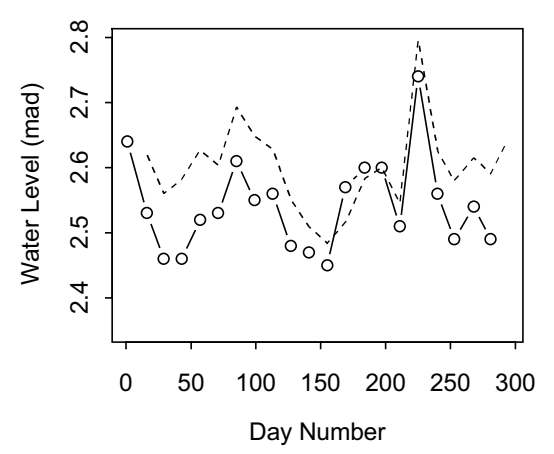

Dipwell 5

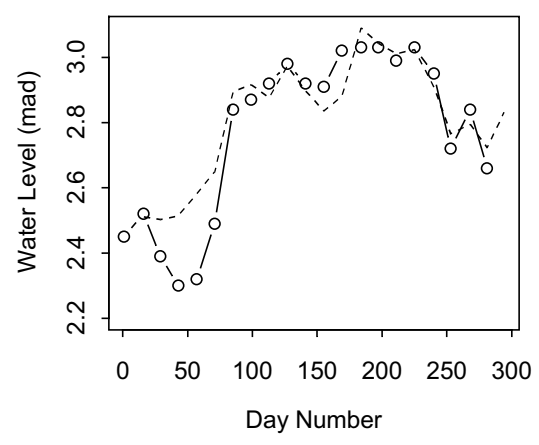

Fig. 5. Observed (solid lines with circles) and predicted (dotted line) water levels in two dip wells on Tadham Moor 
approximately 80 days, the model reproduces the observations more accurately at dipwells near to the centre of the field. This result is expected as the steeper water table gradient close to the ditch is more difficult to model than the flatter gradients near the field centre. The model values are generally within $10 \mathrm{~cm}$ of the observations which, given the heterogeneity of peat permeability (Bromley et al., 2005) and the current lack of site specific evaporation data, is surprisingly accurate.

The model can now be expanded to the entire field and, eventually, will provide a water table level across the whole site. This will aid the interpretation of vegetation survey data and soil microbe greenhouse gas production.

\section{Wetland restoration and flood risk: the case of the North Drain, UK}

Storage of water on floodplain wetlands after heavy rainfall can reduce flood risk downstream. This is one of the most tangible benefits of wetlands. Acreman et al. (2003) showed that flood peaks on the River Cherwell in central England were increased by $150 \%$ by embanking the channel (separating the river from the floodplain) compared with using the floodplain for flood storage. This indicates the potential for restoring the connection between rivers and their floodplains for flood management. The US Corps of Engineers (1972) calculated that 3800 hectares of floodplain storage on the Charles River, Massachusetts would avoid US\$17 million of downstream flood damage each year.

Clearly, for a wetland to act in this way, the storage must be available. A possible conflict arises between hydrological functions and ecological objectives when a wetland water table is maintained at a high level, such that some potential flood storage is already occupied. This issue was studied in the catchment of the North Drain, a $30 \mathrm{~km}^{2}$ sub-catchment of the River Brue, which contains Tealham and Tadham Moors. This catchment was chosen because $88 \%$ of the area is wetland; impacts of wetland storage which could not be demonstrated here would be irrelevant in catchments containing fewer wetlands. In some parts of the catchment, winter water levels were raised under the ESA scheme, introduced under the Agriculture Act (1986) in an attempt to encourage environmentally beneficial farming practices (Tucker and Petterson, 2003). The catchment contains three elements of storage; (1) in the peat soils; (2) in drainage ditches; (3) above ground inundation; all of which can alter flood volumes and peak flows downstream. Raising water levels to mean field level (Tier 3 under the ESA scheme) would effectively remove storage elements (1) and (2) during winter months.

In this study, a geographic information system (GIS) was set up to calculate the impacts on flood risk of implementing Tier 3 wetland restoration. The catchment boundary of the North Drain was determined from local ditch management and flow directions derived from a digital elevation model. The length of ditches in the catchment and field areas under ESA Tier 3 management were calculated from local digital maps and local authority payment records respectively.

Two scenarios were developed. The first compared nonESA conditions with recent Tier 3 coverage. A second compared non-ESA conditions with complete Tier 3 coverage in the peat-covered component of the North Drain catchment, i.e. assuming all farmers took up the ESA scheme. The GIS was used to calculate the volume of storage in all ditches and soils as a difference between Tier 3 water levels (mean field level) and non-Tier 3 (low) water levels created by normal operation of the North Drain pumping station. Total changes in storage were compared with 4.3 $\mathrm{Mm}^{3}$, a volume of the median annual maximum flood $\left(\mathrm{V}_{\text {med }}\right)$, derived using flow records from 1993 to 2000 and the peaks over threshold model of the Flood Estimation Handbook (Robson and Reed, 1999). For soil water storage, a specific yield value of 0.2 was used (Price et al., 2003; Gilman, 1994; Armstrong, 1993).

The results are shown in Table 1. Even with recent Tier 3 coverage at only $0.68 \mathrm{~km}^{2}$, the amount of potential storage taken-up by increased water levels was $1.8 \%$ of $\mathrm{V}_{\text {med }}$, an increase which would have a notable effect on downstream flood events.

The hydrological impacts of wetland restoration is demonstrated by calculating the effect of increasing the Tier 3 prescriptions to cover the entire peat-covered component $\left(26.5 \mathrm{~km}^{2}\right)$ of Tealham and Tadham Moors. The loss of flood storage would be $84 \%$ of a $\mathrm{V}_{\text {med }}$ event.

Table 1. Calculated water volumes in North Drain catchment

\begin{tabular}{|c|c|c|c|c|c|c|}
\hline Scenario & Soil volume & $\begin{array}{l}\text { Soil water } \\
\mathrm{m}^{3}\end{array}$ & $\begin{array}{l}\text { Ditch water } \\
\text { volume } \mathrm{m}^{3}\end{array}$ & $\begin{array}{l}\text { North Drain } \\
\text { volume } \mathrm{m}^{3}\end{array}$ & $\begin{array}{l}\text { Total volume } \\
\text { volume } \mathrm{m}^{3}\end{array}$ & $\begin{array}{l}\% V_{\text {med }} \\
\mathrm{m}^{3}\end{array}$ \\
\hline current Tier 3 & 296,000 & 59200 & 18,700 & N/A & 78,000 & 1.8 \\
\hline \multicolumn{7}{|c|}{ Whole catchment } \\
\hline Tier 3 & $15,000,000$ & $3,016,000$ & 528,000 & 40,170 & $3,584,000$ & 83.8 \\
\hline
\end{tabular}


The North Drain represents an extreme case where $88 \%$ of the catchment is wetland. For other catchments, the loss of storage will likely be a smaller percentage of flood volume. Nevertheless, loss of storage in areas of raised water levels may represent a significant proportion of total flood storage available within the floodplains, which has implications for catchment flood management.

\section{Reconnecting floodplains and river: the case of the Tisza, Hungary}

Implementation of the Water Framework Directive in some EU member states will involve consideration of the ecological and water quality aspects of rivers and their floodplain wetlands. To improve the ecological status of many of Europe's great river systems, there may be a move to increase the hydraulic conductivity between the dredged and canalised rivers and their long abandoned floodplains and oxbow lakes. The positive effects on river water quality (Weng et al., 2003; Brunet et al., 1994; Johnston et al., 1984) and river ecology (Young, 2001) of increased connection of the river with its floodplain wetlands are known. However, the impact of such hydraulic reconnections on the water quality and ecological status of the wetlands is less well understood.

The Tisza River is the largest tributary of the Danube, having a catchment of $157000 \mathrm{~km}^{2}$. The River Tisza has been dredged, straightened, shortened and impounded by flood protection embankments during engineering works that began in the 1880s (Csanyi et al., 2003). Work also disconnected meanders to form more than 150 oxbow lakes. The oxbows on the river side of the flood embankments have received river inputs five times over the past nine years, while those beyond the embankments flood only if the waters breach the embankments. Many of the oxbows have become havens of biodiversity within the Hungarian plains of intensive agriculture. They are characteristically fringed by riparian woodlands and emergent vegetation, have socioeconomic value as fisheries, are sites of recreation and are used for water abstraction for irrigation (Pálfai, 2003a,b). As a result of their use for abstraction, their proximity to agricultural land and their lack of surface inflows, they have become affected by eutrophication, sediment infilling and desiccation (Pálfai, 2003b). Floating-leaved macrophytes, especially Trapa natans, cover the surfaces of many of the oxbows, sometimes to the extent that no open water is visible and macrophyte species diversity is suppressed. Their lack of connection to the main river channel, however, has also spared some of them from the cyanide spills in the River Tisza in 2000.

As part of The River Tisza Project, funded by the European
Commission, the water quality and ecological implications of increasing the hydraulic interaction between the main river channel and floodplain oxbows were investigated on a typical floodplain oxbow in the Tisza basin at Csatloi, on the river side of the flood protection embankment. Water, nutrient and sediment fluxes were estimated using a massbalance approach, with groundwater water movements calculated from a grid of boreholes round Csatloi, and surface water influxes calculated from flood heights over a digital terrain model (ref to main Tisza report).

Total nitrogen (TN) and total phosphorus (TP) inputs into the oxbow were calculated using either relationships between stage height and nutrient concentrations where they existed, or mean seasonal concentrations where they did not. Nitrogen losses within the oxbow were compared with estimates published by Jensen et al., (1992) and Schernewshi (2003) and in-lake P concentrations were calculated using the $\mathrm{P}$ budget equation devised by Osborne (1980) for shallow eutrophic lakes. Using this combined approach, surface water, TN and TP fluxes between the river and oxbow, and the resulting in-lake concentrations were calculated on a daily basis. A comparison between the predicted and actual lake depth using data gathered from July 2003 to May 2004 showed the model to be within $5 \mathrm{~cm}$ of actual recordings. Predicted TN and TP concentrations differed from actual measurements taken on 15 occasions between June 2002 and April 2004 by, for TN a maximum of $0.74 \mathrm{mg}^{-1}$ with a mean of $0.44 \mathrm{mg} \mathrm{l}^{-1}$ and for TP a maximum of $0.3 \mathrm{mg} \mathrm{l}^{-1}$ with a mean of $0.068 \mathrm{mg}^{-1}$. In-lake chlorophyll-a concentrations were calculated as a function of TP, TN and air temperature. Pre-existing generalised equations which predict the relationship between chlorophyll and $\mathrm{P}$ concentrations were not appropriate as these were developed for deep lakes, where P is often limiting, rather than for shallow lakes where either $\mathrm{N}$ or $\mathrm{P}$ can be the limiting nutrient (James et al., 2003; Fisher, 2003; van de Molen et al., 1998).

The in-lake water depth, sediment inputs, TN, TP and chlorophyll concentrations were calculated for the current situation from 1996 to 2004 and compared with the same variables predicted by lowering the elevation at which the Tisza River can flow into the oxbow by $75 \mathrm{~cm}$.

Table 2 summarises the monitored water quality characteristics of Csatloi and the Tisza River. Growth season (GS) (May-October) and winter season (WS) (NovemberApril) concentrations are shown separately only where differences between the two are significant $(p<0.05)$. The results show that if flooding frequency into the oxbow is increased, in-lake TP concentrations will decrease, but TN increases (Fig. 6 a,b). This is to be expected, given that the Tisza river has similar TP concentrations but greater TN concentrations than the oxbow (Table 2). TP concentrations 
Table 2. Summary of the mean growth season (GS), winter season (WS) or annual concentrations of nutrients, suspended sediment and chlorophyll in the Csatloi oxbow $(\mathrm{n}=12)$ and River Tisza $(\mathrm{n}=174)$. Separate values for growth and winter seasons are shown where there is a significant $(\mathrm{p}<0.05)$ difference between seasons.

\begin{tabular}{lllllll}
\hline & \multicolumn{3}{c}{ Csatlor } & & \multicolumn{3}{c}{ Tisza } \\
& $G S$ & $W S$ & Annual & $G S$ & $W S$ & Annual \\
\hline Total nitrogen $\left(\mathrm{mg} \mathrm{l}^{-1}\right)$ & $\mathrm{n} / \mathrm{a}$ & $\mathrm{n} / \mathrm{a}$ & 0.9 & 1.66 & 2.29 & $\mathrm{n} / \mathrm{a}$ \\
Nitrate-N $\left(\mathrm{mg} \mathrm{l}^{-1}\right)$ & 0.23 & 0.59 & $\mathrm{n} / \mathrm{a}$ & 1 & 1.69 & $\mathrm{n} / \mathrm{a}$ \\
Total phosphorus $\left(\mu \mathrm{g} \mathrm{l}^{-1}\right)$ & 117 & 153 & $\mathrm{n} / \mathrm{a}$ & $\mathrm{n} / \mathrm{a}$ & $\mathrm{n} / \mathrm{a}$ & 153 \\
Orthophosphate $\left(\mu \mathrm{g} \mathrm{l}^{-1}\right)$ & $\mathrm{n} / \mathrm{a}$ & $\mathrm{n} / \mathrm{a}$ & 25 & $\mathrm{n} / \mathrm{a}$ & $\mathrm{n} / \mathrm{a}$ & 63 \\
Suspended sediment $\left(\mathrm{mg} \mathrm{l}^{-1}\right)$ & $\mathrm{n} / \mathrm{a}$ & $\mathrm{n} / \mathrm{a}$ & 15 & $\mathrm{n} / \mathrm{a}$ & $\mathrm{n} / \mathrm{a}$ & 58 \\
Chlorophyll-a $\left(\mu \mathrm{g} \mathrm{l}^{-1}\right)$ & 24 & 2 & $\mathrm{n} / \mathrm{a}$ & $\mathrm{n} / \mathrm{a}$ & $\mathrm{n} / \mathrm{a}$ & 6.8 \\
\hline
\end{tabular}
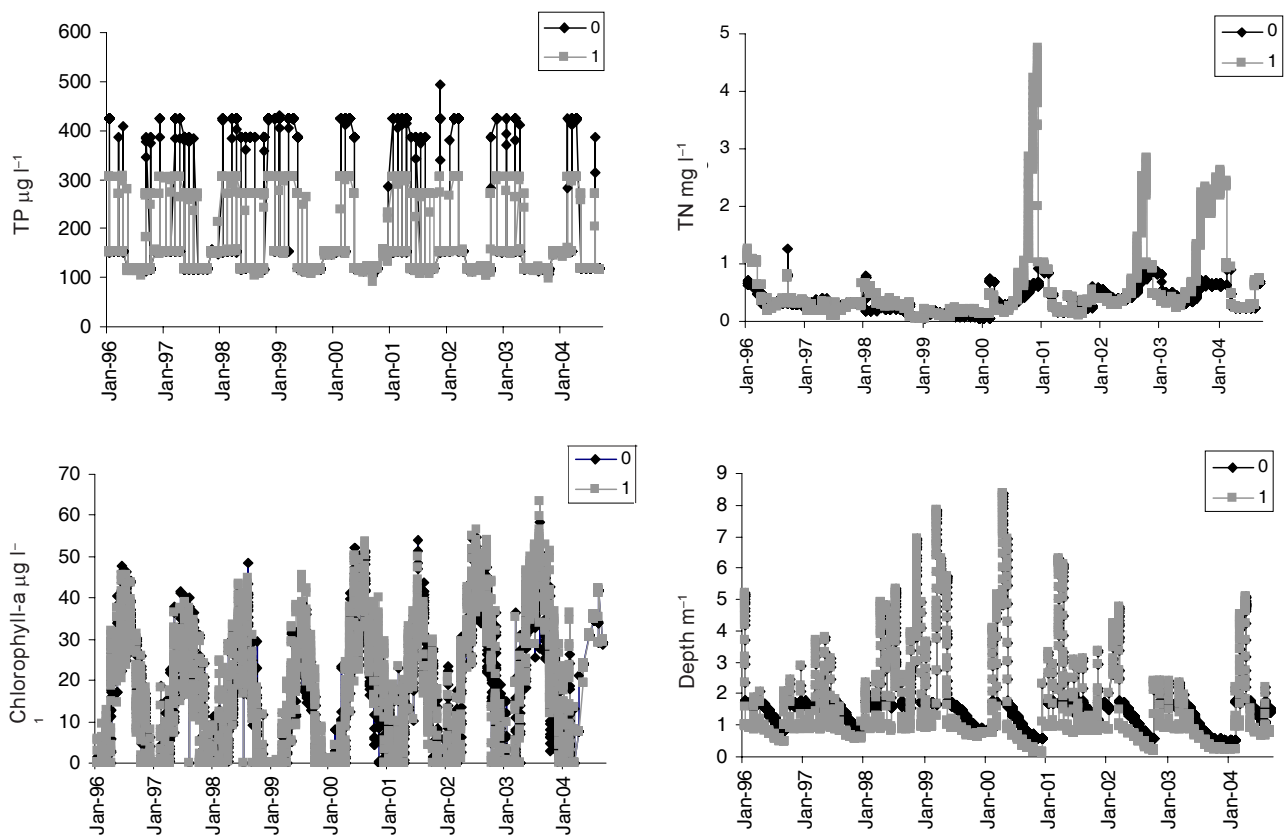

Fig. 6. Predicted TP concentration, TN concentration, chlorophyll-a concentration and lake depth of Csatloi oxbow as a result of increased flood interaction with the Tisza River. $0=$ present situation, $1=$ prediction if elevation at which river could flood into oxbow was reduced by $75 \mathrm{~cm}$.

are predicted to be lower as a result of the reduced residencetime which is a function of Osborne's (1980) P budget equation. Lower residence-times are likely to reduce $\mathrm{P}$ sedimentation in the lake and facilitate $\mathrm{P}$ export from the lake when flood waters drain. The influxes of nitrogen may have implications for the eutrophication of Csatloi as it is characterised by a low N:P ratio (TN:TP $<10$ by weight) which suggests a tendency towards $\mathrm{N}$ limitation in summer. The result is expected given that Csatloi is shallow, eutrophic and macrophyte-dominated, a type likely to be $\mathrm{N}$-driven (Fisher, 2003; James et al. 2003, van de Molen et al., 1998). The situation could result in an increase in phytoplankton standing stock, though the predicted chlorophyll-a concentrations do not reflect this (Fig. 6c). This may be a result of the corresponding decrease in TP concentrations a result of the flushing effect of the inflows which have TP concentrations similar to the oxbow, while TN concentrations in the river are much greater than those in the oxbow (Table 2). Figure 6d shows that reconnection will increase lake level fluctuation, with the lake drying out some years and these may lead to a loss of emergent and submerged macrophytes (Coops et al., 2003).

The Tisza case study illustrates that while increased interaction between river and its floodplain wetlands may benefit river ecology, water quality and hydrology, the effects on wetlands that have been long abandoned as a result 
of anthropogenic activity have to be considered. The input of floodwaters into floodplain wetlands can alter the hydrological and nutrient budgets as well as causing direct physical disturbance. Natural floodplain-wetlands that have developed in response to frequent disturbance may have a high biodiversity (Van Geest et al., 2005) but those that have developed in infrequently disturbed conditions will not be so well adapted. A renewed period of river-floodplain interaction may result in reduced ecological status and water quality before the wetland flora and physical and chemical functioning adapt to the new regime. The case of the River Tisza oxbows may be a valuable example of the problems faced when attempting to naturalise floodplain wetlands adjacent to a heavily modified river.

\section{Planning large-scale wetland restoration: is there enough water? - the case of the Great Fen, UK}

Over the past two millennia, the Fenland basin of eastern England has changed from a primeval wetland of fens, swamp, carr and open water to an almost entirely arable landscape, such that by 1900 , only three small areas of 'wild' fen habitat survived i.e. $<0.1 \%$ of the original resource (Colston 2003). In that time, many species were lost entirely from Fenland e.g. Large Copper butterfly (Lycaena $d$. dispar) and Marsh Fleawort (Tephroseris palustris) and the range and population of many others declined catastrophically..

From the early 1990s, a 'Wet Fens for the Future' programme stimulated wetland restoration, habitat conservation and new livelihoods for the people of the Fenland and, by 2005, six major ecological restoration schemes had begun, to re-create fens, swamps, wet grassland and open water on land that could be released from agricultural production. One of the largest of these restoration schemes is at the western margin of the basin: the Great Fen, linking Holme and Woodwalton National Nature Reserves (Gerrard, 2004). A core of highly modified wetland habitat in the nature reserves is surrounded by land that has been pump-drained over several centuries and converted to intensive arable agriculture.

For the ecological restoration of wetlands to be successful, it is usually assumed that the restored habitat must have a comparable composition, productivity and nutrient retention to the 'target habitat', and that it must be sustainable (i.e. capable of perpetuating itself without frequent human intervention). Further, it must resist invasion by new species, and all components and biotic interactions must be in place, i.e. it must have functional integrity (Hughes et al., 2005).
For the wetland complexes of the Fenland basin, it was axiomatic that successful restoration should be based upon appropriate hydrology. To that end, the restoration schemes have undertaken eco-hydrological research to ensure that the correct amount of water is available at the right time of year and that it is of suitable quality.

In the particular example of the Great Fen, CEH was commissioned to assess the scheme area (Mountford et al., 2002), and answer the following hydro-ecological questions:

(a) What were the water resources within the scheme area, their present usage and their potential availability for restoration?

(b) What were the likely water demands of re-created wetland habitats in the scheme area?

(c) How would these demands be affected under scenarios of climate change?

(d) Integrating water-regime requirements of vegetation with likely water resources, which habitats could be restored, in which parts of the scheme area and how extensive would they be?

The first step was to provide background information on the water-regime requirements of those plant species and vegetation communities that were central to the vision of the target wetlands. Considerable progress has been made in relating the composition of vegetation to the prevailing and historical water regimes and, in recent years, there has been a focus on the water-supply mechanism under which the (semi-) natural community occurs normally (Wheeler et al., 2004) and the use of Sum Exceedence Values (Sieben, 1965) to quantify how much a habitat could be stressed by drought or waterlogging before it was damaged (e.g. Gowing et al., 2002). The Great Fen research also assessed the use of evaporation to characterise how much water a habitat or community required and consumed (Mountford et al., 2002). This approach allowed the restoration planners to compare, directly, the water-regime needs of the arable crops present now with those of restored wetland habitats. To assess vegetation water requirements, the Great Fen work adopted the crop coefficient methodology (Allan et al., 1998), which has lately been increasingly applied to non-crop vegetation (Fermor et al., 2001).

Looking at the Great Fen scheme area, the ecologists characterised the present vegetation and distribution of species both within the relict fens and throughout the arable landscape. At the same time, the hydrologists quantified the water resources for the scheme area, identified where and in what quantities water entered and left the area and what demands were made of that water by both nature conservationists and farmers. The resultant water budget 
could be altered to take account of potential changes in (a) the management of the streams feeding the scheme area; (b) the potential diversion from adjacent catchments through the drainage network; (c) differences in evapotranspiration from a variety of wetland and crop types; and (d) changes to abstraction and/or the amount of water leaving the scheme area through the Bevill's Leam pump (the control structure on the only outlet from the Great Fen area).

The focus of the hydro-ecological work was to compare the requirements of the target habitats with the practicality and likelihood that these conditions could be provided in the scheme area. Figure 7 shows a clear summer water deficit for wetland vegetation, with insufficient water to meet full evaporative demand (mean shortfall for reedswamp ca. 3.3 million $\mathrm{m}^{3}$ ).

If wetland restoration were to be attempted over most of the scheme area, then some of the winter excess water would have to be stored to meet summer demand. A soil moisture accounting model was used to assess the implications of different volumes of storage plus the duration/severity of any stress period (drought, etc.) (Mountford et al., 2002). The relationship between the amount of water storage and the area of wetland that could be supported was examined and predictions were made under a range of scenarios, assuming that it would be possible to move water around and that there is no continued requirement for agricultural irrigation within the scheme area. It was concluded that there was sufficient water for the whole restoration scheme in $84 \%$ of years, assuming that winter discharge (from the scheme area) at the outlet pump could be reduced significantly. At other times, some diversion from other catchments might be considered.

To supply working design options for the Great Fen project, soil moisture accounting models were used to estimate: (a) the water balance; (b) the area of each habitat that could be supported; (c) the between-year variation in water-balance; and (d) the potential stress on the target habitats. The context for these plans was an assumption that the restored Great Fen would consist of a mosaic of habitats, including dry and wet grassland and a complex of fen, reed and open water. Each habitat was modelled separately but linked by water-fluxes, with two external resources: summer irrigation (for wet grassland) and topping up of the fen complex in the winter. Rainfall, transpiration and drainage were factors in each model, which predicted soil-moisture deficit, evaporation rates and average annual runoff. The scenarios were then integrated through a Geographical Information System, using output from the models and micro-topographic information derived from LIDAR imagery. The approach assumed a winter take-off of $3 \mathrm{Mm}^{3}$ for reed and open water, and a potential summer take of up to $1.8 \mathrm{Mm}^{3}$. The habitat types were distributed on the basis of elevation. Up to $7.2 \mathrm{~km}^{2}$ of fen (water-levels allowed to fall naturally through the summer) and $5.0 \mathrm{~km}^{2}$ of wet grassland (requiring summer irrigation) could be restored in the scheme area under this scenario, provided there was winter storage of $3 \mathrm{Mm}^{3}$ of upland runoff. The remainder of the site might initially be restored to dry grassland. Such calculations assume current climate conditions. However, the evidence is persuasive that the climate is changing with resulting potential impacts on water available to the Great Fen scheme. Amongst the various possible scenarios, one (the UKCIP Medium-high forecast) was tested for its possible impact on the project. This scenario includes a reduction in summer rain of $39 \%$ by 2080 , an increase in summer evaporation by $48 \%$ and an increase in winter rainfall of $21 \%$. This implies a need for more storage capacity or a reduced area of restored wetland.

Hydro-ecological science is being used to ensure that both viable farming and successful habitat restoration can co-

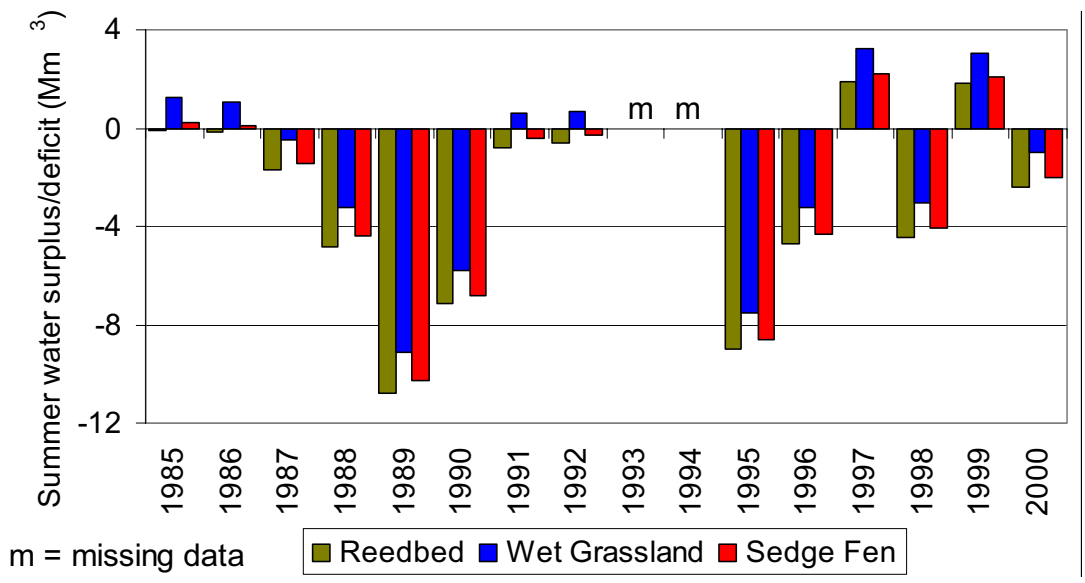

Fig. 7. Great Fen Project: Water deficit if the entire restored area was covered with specified wetland habitats 
exist within this region. It is likely that such research will become yet more intimately involved in environmental planning for fenland.

\section{Conclusions}

This paper has described some of the major hydrological issues associated with the restoration of wetlands in Europe.

- Water availability for restoration at required times The Great Fen case study shows that, due to competing demands for water resources (such as abstraction for agriculture and public supply), there may not be sufficient water available in summer to achieve restoration without water storage or diversion from other catchments. Furthermore, water may become more scarce under a future climate when rainfall is likely to decrease and evaporation to increase in summer.

- The role of models in assessing the likely success of restoration

In all the case studies, models have proved invaluable in identifying and quantifying hydrological interactions between the wetland and surrounding ditches (Tadham Moor), river (Tisza) and catchment (Great Fen). Such models provide an inexpensive way of assessing wetland restoration methods and needs. Wetland modelling, especially over a larger catchment scale, however, is still in its infancy and the issues highlighted here point towards a need for models than can work on both site specific and catchment scales.

- The effectiveness of ditch water level management on in-field wetness

Manipulation of ditch water levels is a key management tool in many wetlands. However, the Tadham Moor case study has demonstrated that because of the low hydraulic conductivity of wetland soils, desired water table levels may be achieved only immediately adjacent to the ditches.

- The utility of reconnecting river channels to floodplains and oxbow lakes

Studies into the feasibility of wetland restoration at Tadham Moor and of the River Tisza oxbows highlight that where wetland morphology has been altered, hydrological solutions alone may be insufficient to bring about the desired restoration. As a result of the lowering of the bed of the River Tisza bed in relation to its floodplain and the loss of natural shallow channels over Tadham Moor, the re-flooding or rewetting efforts are unlikely to bring about the desired natural fluctuations in the water balances of these wetlands. Restoration efforts must consider the re-instalment of natural landscape features, where possible, as well as manipulating the hydrology.

- The impact of restoration on the hydrological function of wetlands

Restoration of Tadham wetlands results in a loss of potential flood storage within the North Drain catchment. While the Tisza oxbows are also potential flood storage reservoirs, the occasional influx of nutrient-rich water, sediment and changes in water levels could reduce the ecological status of the oxbows, though flood storage and increased flooding of the river onto its wetlands may benefit the Tisza River hydrology, water quality and ecology.

These case studies highlight that wetland restoration is a large balancing act, taking into account on the one hand wetland specific water resource requirements, hydrology, wetland morphology and ecological value and on the other hand, the role of that wetland within the catchment and the effect of such restoration on wider hydrological and ecological priorities.

These examples of wetlands are from temperate Europe, where considerable knowledge and data exist. Yet, even here, major gaps in understanding could lead to inappropriate restoration measures. Moreover, many of the most threatened international wetlands are in developing countries where few data exist and little research is being undertaken. It is not possible to transfer knowledge of temperate European wetlands directly to ephemeral wetlands in the arid and semi-arid regions of the Mediterranean or Middle East. Important decisions have to be taken on the protection of wetlands, such as dambos in Zimbabwe, even though knowledge is sparse and contradictory (McCartney, 2000). Improving guidance on wetland restoration will require considerable future research, hydrological data and models capable of predicting the consequences of options before expensive and irreversible actions are taken.

\section{References}

Acreman, M.C., Mountford, J.O., McCartney, M.P., Wadsworth, R.A., Swetnam, R.D., McNeil, D.D., Manchester, S.J., Myhill, D.G., Broughton, R.K. and Hudson, J., 2000. Integrating wetland management, catchment hydrology and ecosystem functions. Annual Report. CEH, Wallingford, UK. 112pp.

Acreman, M.C., Riddington, R. and Booker, D., 2003. Hydrological impacts of flood- plain restoration. Hydrol. Earth Syst. Sci., 7, 75-86. 
Allan, R.G., Pereira, L.S., Raes, D. and Smith, M., 1998. Crop evapo-transpiration: guidelines for computing crop water requirements. FAO Irrigation and Drainage Paper 56, FAO, Rome, Italy. 87pp.

Armstrong, A.C., 1993. Modelling the response of in-field water tables to ditch levels imposed for ecological aims: a theoretical analysis. Agr. Ecosyst. Environ., 43, 345-351.

Bradford, R. and Acreman, M.C., 2003. An application of MODFLOW to assess the hydrological functioning of the Pevensey Levels, a low wet grassland in East Sussex, UK. Hydrol. Earth Syst. Sci., 7, 43-56.

Bradley, C. and Brown, A.G., 1995. Shallow groundwater modeling and the overbank contribution to a small floodplain bog. In: Geomorphology and Groundwater, A.G. Brown (Ed.), Wiley, Chichester, UK. 22-45.

Bromley, J., Robinson, M. and Barker, J.A., 2004. Scaledependency of hydraulic conductivity: an example from Thorne Moor, a raised mire in South Yorkshire, UK. Hydrol. Process., 18, 973-985.

Brunet, R.C., Pinay, G., Gazelle, F. and Roques, L., 1994. Role of the floodplain and riparian zone in suspended matter and nitrogen retention in the Adour River, South-West France. Regul. River.: Res. Manage., 9, 55-63.

Bullock, A. and Acreman, M.C., 2003. The role of wetlands in the hydrological cycle. Hydrol. Earth Syst. Sci., 7, 75-86.

Csanyi, B., Gulyas, P., Nemeth, J. and Kavron, V., 2003. Ecological characteristics of the Tisza River and its oxbows. Internal report for VITUKI, H-1095 Budapest, Kvassay Jenõ út 1, H-1453 Budapest, Hungary.

Colston, A., 2003. Beyond preservation the challenge of ecological restoration. In: Decolonising nature; strategies for conservation in a post-colonial era. W.M. Adams and M. Mulligan (Eds.), Earthscan, London, UK. 213pp.

Coops, H., Beklioglu, M. and Crisman, T.L., 2003. The role of water-level fluctuations in shallow lake ecoystems - workshop conclusions. Hydrobiologia, 506-509, 23-27.

Dahl, T.E. and Johnson, C.E., 1991. Wetlands status and trends in the conterminous United States. US Department of Interior, Fish and Wildlife Service, Washington D.C., USA. 28pp.

Davis, T.J., 1994. The Ramsar Convention manual. A guide to the Convention on wetlands of international importance. Ramsar Convention Bureau, Gland, Switzerland. 207pp.

Dugan, P.J., 1993. Wetland conservation - a review of current issues and required actions. IUCN, Gland, Switzerland. $101 \mathrm{pp}$.

Fisher, J., 2003. Nitrogen-limited lakes: their occurrence, basis and characteristics. PhD Thesis, University of Liverpool, UK. $275 \mathrm{pp}$.

Gavin, H., 2003. Scoping study on guidance for the monitoring of wetlands under the requirements of the Water Framework Directive. WFD Technical Report EMC(02)01\TR. Environment Agency, Bristol, UK. 85pp.

Fermor, P.M., Hedges, P.D., Gilbert, J.C. and Gowing, D.J.G., 2001. Reedbed evapo-transpiration rates in England. Hydrol. Process., 15, 621-631.

Gerrard, C., 2004. The Great Fen project. http:// www.greatfen.org.uk/project.pdf

Gilman, K., 1994. Hydrology and Wetland Conservation. Wiley, Chichester, UK. $101 \mathrm{pp}$.

Gowing, D.J.G., Lawson, C.S., Youngs, E.G., Barber, K.R., Rodwell, J.S., Prosser, M.V., Wallace, H.L. Mountford, J.O. and Spoor, G., 2002. The water regime requirements and the response to hydrological change of grassland plant communities. Final report by Cranfield University to Defra (Project BD1310). 85pp.
Hughes, F.M.R., Colston, A. and Mountford, J.O., 2005. Restoring riparian ecosystems: the challenge of accommodating variability and designing restoration trajectories. Ecol. Society 10, art.12 URL: http://www.ecologyandsociety.org/vol10/iss1/art12/

Hollis, G.E. and Thompson, J.R., 1998. Hydrological data for wetland management. J. Chart. Inst. Water Environ. Manage., 12, 9-17.

James, C., Fisher, J. and Moss, B., 2003. Nitrogen-driven lakes: The Shropshire and Cheshire Meres. Arch. Hydrobiol., 158, 249 266

Jensen, J.P., Jeppesen, E., Kristensen, P., Bondo, P., Sondergaar, C. and Sondergaard, M., 1992. Nitrogen loss and denitrification as studied in relation to reductions in nitrogen loading in a shallow, hypertrophic lake (Lake Sobygard, Denmark). Int. Rev. Gesamten Hydrobiol., 77, 29-42.

Johnston, C.A., Bubenzer, G.D., Lee, G.B., Madison, F.W. and McHenry, J.R., 1984. Nutrient trapping by sediment deposition in a seasonally flooded lakeside wetland. J. Environ. Qual., 13, 283-290.

Maltby, E., Immirzi, C.P. and Safford, R.J., 1996. Tropical lowland peatlands of southeast Asia. IUCN, Gland, Switzerland. 293pp.

McCartney, M.P., 2000 The water budget of a headwater catchment containing a dambo. Phys. Chem. Earth. B. 25, 611-616.

McCartney, M., de la Hera, A., Acreman, M.C. and Mountford, M.O., 2000. An investigation of the water budget of Wicken Fen. Report to National Trust. CEH Wallingford, UK. 76pp.

McDonald, M.G. and Harburgh, A.W., 1988. A modular threedimensional, finite difference groundwater flow model. Techniques of Water Resources Investigations. Book 6, Chapter A1, US. Geological Survey, Washington, D.C., USA. 87pp.

Meynell, P-J. and Qureshi, M.T. 1995 Water resources management in the Indus river delta, Pakistan. Parks - Intern. J. Prot Area Mang. 5, 2, 15-23.

Mitsch, W.J. and Gosselink, J.G., 1993. Wetlands. Van Nostrand Reinhold, New York, USA.

Mountford, J.O., McCartney, M.P, Manchester, S.J. and Wadsworth, R.A., 2002. Wildlife habitats and their requirements within the Great Fen Project. Final CEH report to the Great Fen Project Steering Group, CEH, Monks Wood, UK. 87pp.

Négrel, P., Sgouridis, F., Petelet-Giraud, E. and Maltby, E., 2005. EUROWET: Integration of European wetland research in sustainable management of the water cycle. Final report. GOCECT-2003-505586. European Commission, Brussels. 302pp.

Organisation for Economic Cooperation and Development, 1996. Guidelines for aid agencies for improved conservation and sustainable use of tropical and sub-tropical wetlands. Guidelines on aid and environment No 9. OECD, Paris, France. 91pp.

Osborne, P.L., 1980. Predictions of phosphporus and nitrogen concentrations in lakes from both internal and external loading rates. Hydrobiologia, 69, 339-233.

Pálfai, I., 2003a. Oxbow lakes in Hungary. Ministry of Environmental Control and Water Management, Budapest, Hungary.

Pálfai, I., 2003b. The hydrology and rehabilitation of oxbow lakes of the Hungarian section of the River Tisza. Translated by M. Mondaki. Ministry of Environmental Control and Water Management, Szeged, Hungary. 128pp.

Price, J.S., Heathwaite, A.L. and Baird, A.J., 2003. Hydrological processes in abandoned and restored peatlands: an overview of management approaches. Wetlands Ecol. Manage., 11, 65-83.

Ramsar Convention Bureau, 2000. Developing and implementing National Wetland Policies. Ramsar handbooks for the wise use of wetlands No 2. Ramsar Convention Bureau, Gland, Switzerland. 
Robson, A. and Reed, D., 1999. Flood Estimation Handbook Volume 3: Statistical Procedures for Flood Frequency Estimation. Institute of Hydrology, Wallingford, UK. 338pp.

Schernewski, G., 2003. Nutrient budgets, dynamics and storm effects in a eutrophic, stratified Baltic Lake. Acta Hydrochim. Hydrobiol., 31, 152-161.

Scott, D.A. and Poole, C.M., 1989. A status overview of Asian wetlands. Asian Wetland Bureau, Kuala Lumpur, Malaysia. $121 \mathrm{pp}$.

Scudder, T. et al., 1993. The IUCN review of the Southern Okavango Integrated Water Development Project. IUCN, Gland, Switzerland. 543pp.

Sheail, J., Treweek, J.R. and Mountford, J.O., 1997. The UK transition from nature conservation to "creative conservation". Environ. Conserv., 24, 224-235.

Sieben, W.H., 1965. Het verband tussen outwatering en obrengst bij de jonge zavelgranden in de Noordoostpolder. Van Zee Tot Land., 40, 1-117.

Tucker, G. and Petterson, D., 2003. Review of agri-environmental schemes - monitoring information and research and development results (Parts A and B). Ecoscope, St. Ives, UK. $293 \mathrm{pp}$.

US Corps of Engineers, 1972. Cited by Slather, J.M. and Smith, R.D., 1984. An overview of major wetland functions and values. US Fish and Wildlife Service, FWS/OBS-84/18.

van der Molen D.T., Portielje R., de Nobel W.T. and Boers, P.C.M., 1998. Nitrogen in Dutch freshwater lakes: trends and targets. Environ. Pollut., 102, 553-557. van Geest, G.J., Wolters, H., Roozen, F.C.J.M., Coops, H., Roijackers, R.M.M., Buijse, A.D. and Scheffer, M., 2005. Waterlevel fluctuations affect macrophyte richness in floodplain lakes. Hydrobiologia, 539, 239-248.

Wheeler, B.D., Shaw, S.C., Fojt, W.J. and Robertson, R.A., 1995. Restoration of temperate wetlands. Wiley, Chichester, UK. 562 pp.

Wheeler, B.D., Gowing, D.J.G., Shaw, S.C., Mountford, J.O. and Money, R.P., 2004. Eco-hydrological Guidelines for Lowland Wetland Plant Communities. Environment Agency, Bristol, UK. 85pp.

Weng, P., Sanchez-Perez, J.M., Sauvage, S., Vervier, P. and Giraud, F., 2003. Assessment of the quantitative and qualitative buffer function of an alluvial wetland: hydrological modelling of a large floodplain (Garonne River, France). Hydrol. Process. 17, 2375-2392.

Whiteman, M., José, P., Grout, M., Brooks, A., Quinn, S. and Acreman, M.C., 2004. Local impact assessment of wetlands from hydrological impact to ecological effects. In: Hydrology: Science and practice for the 21st Century, B. Webb, M. Acreman, C. Maksimovic, H. Smithers. and C. Kirby (Eds.) Volume II, Proceedings of the British Hydrological Society International Conference, London, July 2004. 198-212.

Young, W.J., 2001. Rivers as ecological systems: the MurrayDarling Basin. CSIRO, Canberra, Australia. 58pp.

Zwrats, L., van Beukering, P., Kone, B. and Wymenga, E., 2005. The Niger, a lifeline. Effective management in the upper Niger Basin. RIZA/Wetlands International/Institute for Environmental Studies. The Netherlands. 304pp. 